\title{
ATP-Dependent DNA Helicase PIF1
}

National Cancer Institute

\section{Source}

National Cancer Institute. ATP-Dependent DNA Helicase PIF1. NCI Thesaurus. Code C137967.

AT P-dependent DNA helicase PIF1 (641 aa, $70 \mathrm{kDa}$ ) is encoded by the human PIF1 gene. This protein plays a role in the unwinding of G-quadruplex DNA and RNA-DNA hybrids. 